\title{
The 3D Elevation Program-Supporting California's Economy
}

\section{Introduction}

California faces unprecedented challenges presented by shifting weather patterns that are defining a "new normal." The result has been extreme weather events, prolonged drought, flooding, and debris flows. These conditions drive severe tree mortality, increase wildfire occurrence and intensity, reduce water availability, and hasten subsidence in groundwater basins. Collectively, these challenges threaten public safety, compromise infrastructure, and adversely impact the economic well-being of California's citizens. Critical applications that address these issues depend on light detection and ranging (lidar) data that provide a highly detailed three-dimensional (3D) model of the Earth's surface.

The 3D Elevation Program (3DEP; see sidebar) works in partnership with Federal, State, Tribal, U.S. territorial, and local agencies to acquire consistent lidar coverage at quality level 2 or better (table 1) to meet the needs of California (Roth, 2018) and the Nation. The status of publicly available lidar data in California is shown in figure 1. The National Enhanced Elevation Assessment (NEEA) (Dewberry, 2012) identified user requirements and conservatively estimated that availability of lidar data would result in at least \$28 million in new benefits annually to the State. The top six California business uses for 3D elevation data, which are based on the estimated annual conservative benefits of 3DEP, are shown in table 2.

Table 1. Data quality levels, pulse spacing, and pulse density. Quality level 2 or better lidar data meet 3DEP requirements.

[Specifications are from Sugarbaker and others (2014, table 1). In the quality level column, QL0 represents the highest level of quality. RMSE, root mean square error in the elevation $(z)$ dimension; $\mathrm{cm}$, centimeter; $\mathrm{m}$, meter; $\mathrm{pls} / \mathrm{m}^{2}$, first return pulses per square meter; $\leq$, less than or equal to; $\geq$, greater than or equal to]

\begin{tabular}{cccc}
\hline $\begin{array}{c}\text { Quality } \\
\text { level }\end{array}$ & RMSE $_{\boldsymbol{Z}}$ & $\begin{array}{c}\text { Aggregate } \\
\text { nominal } \\
\text { pulse } \\
\text { spacing } \\
\text { (m) }\end{array}$ & $\begin{array}{c}\text { Aggregate } \\
\text { nominal } \\
\text { pulse } \\
\text { density } \\
\left.\text { (pls/m } / \mathbf{m}^{2}\right)\end{array}$ \\
\hline QL0 & $\leq 5 \mathrm{~cm}$ & $\leq 0.35$ & $\geq 8.0$ \\
QL1 & $\leq 10 \mathrm{~cm}$ & $\leq 0.35$ & $\geq 8.0$ \\
QL2 & $\leq 10 \mathrm{~cm}$ & $\leq 0.71$ & $\geq 2.0$ \\
\hline
\end{tabular}

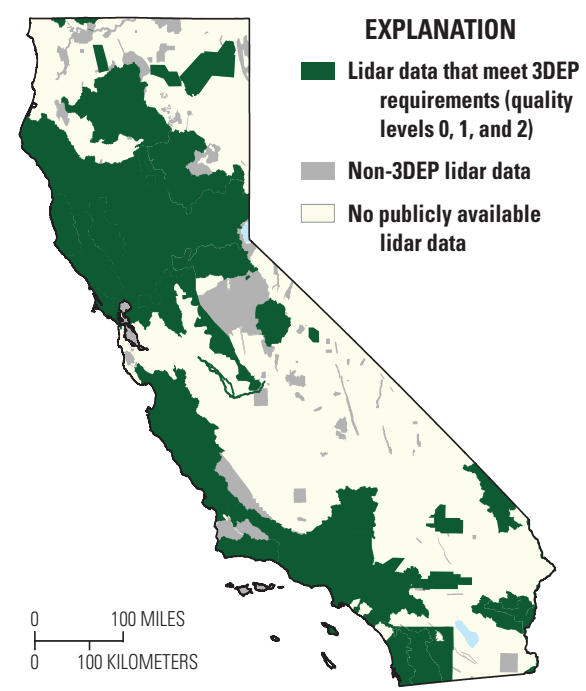

Figure 1. Map of California showing the areal extent and quality levels of existing and in-progress publicly available lidar data as of June 2019. Quality level 2 or better lidar data meet 3DEP requirements. See table 1 for quality level information.

\section{Infrastructure and Construction Management}

California has approximately $\$ 187$ billion in unmet infrastructure needs: $\$ 50$ billion in flood management, $\$ 59$ billion in deferred highway maintenance, and $\$ 78$ billion in local streets and roads (The Planning Report, 2017).

Using lidar data reduces the time required for project planning, resulting in cost savings. Lidar data can be used for preliminary highway alignment and design and for estimating earthwork quantities, evaluating existing roadway conditions, and identifying safety projects. 3D elevation data can also (1) help to improve compliance with building and environmental regulations, (2) enhance the evaluation of project sites, (3) provide input to hydrologic and hydraulic modeling to improve the design of structures (bridges and culverts), and (4) be integrated with geologic and engineering data to expedite project review and reduce costs.

\section{Flood Risk Management}

California's proposed four-point plan (The Planning Report, 2017) to bolster dam safety and flood protection can benefit from lidar data that support more accurate and less expensive hydrologic and hydraulic modeling for flood studies, retention-dam design, dam breach studies, and stormwater management and engineering. This information can be used to identify vulnerable properties within a flood plain, facilitate better flood-plain-management decisions, and educate the public on flood risk zones by providing dynamic 3D models to show the potential impact of flooding from major storm events.

\section{Wildfire Management, Planning, and Response}

In recent years, California has experienced record-setting wildfires and subsequent debris flows triggered after heavy rain events. In addition to the tragic loss of life, more than 24,000 homes and structures have been destroyed, inflicting tremendous human and financial losses. Up-to-date lidar data are used to map the buildup of potentially dangerous biomass fuels in wildland/urban interface areas (fig. 2). The high-resolution 3D elevation data support fire behavior modeling, fire response, vegetation-load appraisal, and post-fire assessment for slope instability, leading to improved public safety.

\section{Geologic Resource Assessment and Hazard Mitigation}

Geologic mapping and mineral assessment can be performed more efficiently and accurately using lidar data. The California Geological Survey's annual production summary reported the top five nonfuel mineral commodities in 2016 were construction sand and gravel, portland cement, boron minerals, crushed stone, and soda ash, with a total production value of $\$ 3.4$ billion. Aggregate materials are essential to maintain the existing infrastructure and to provide for new construction.

Lidar-derived digital terrain models, and derivative products such as slope, aspect, contour, profile, and shaded relief, inform the development of regulatory zones and the assessment and planning related to hazards such as faults, landslides, tsunamis, and flooding.

\begin{tabular}{|lr|}
\hline 3DEP by the Numbers: California \\
Expected annual benefits & $\$ 28.16$ million \\
$\begin{array}{l}\text { Estimated cost for quality } \\
\text { level } 2 \text { completion }\end{array}$ & $\$ 22.95$ million \\
$\begin{array}{l}\text { Payback } \\
\text { Quality level } 1 \text { buy-up } \\
\text { estimate }\end{array}$ & 0.81 years \\
\hline
\end{tabular}


Table 2. Conservative benefits estimates for the top six California business uses of the proposed 3DEP data identified in the National Enhanced Elevation Assessment (Dewberry, 2012).

\begin{tabular}{llc}
\hline Rank & \multicolumn{1}{c}{ Business use } & $\begin{array}{c}\text { Annual } \\
\text { benefits } \\
\text { (millions) }\end{array}$ \\
\hline 1 & $\begin{array}{c}\text { Infrastructure and con- } \\
\text { struction management }\end{array}$ & $\$ 8.37$ \\
\hline 2 & $\begin{array}{c}\text { Natural resources } \\
\text { conservation }\end{array}$ & 4.37 \\
\hline 3 & $\begin{array}{l}\text { Flood risk management } \\
\text { Wildfire management, } \\
\text { planning, and } \\
\text { response }\end{array}$ & 4.22 \\
\hline 5 & $\begin{array}{l}\text { Agriculture and precision } \\
\text { farming }\end{array}$ & 2.02 \\
\hline 6 & $\begin{array}{l}\text { Geologic resource } \\
\text { assessment and hazard } \\
\text { mitigation }\end{array}$ & 1.66 \\
\hline & \begin{tabular}{l} 
Other \\
\hline
\end{tabular} & Total \\
\hline
\end{tabular}

${ }^{1}$ In the years since the release of the National Enhanced Elevation Assessment (Dewberry, 2012), it is likely that the benefits estimate for wildfire management, planning, and response has increased.

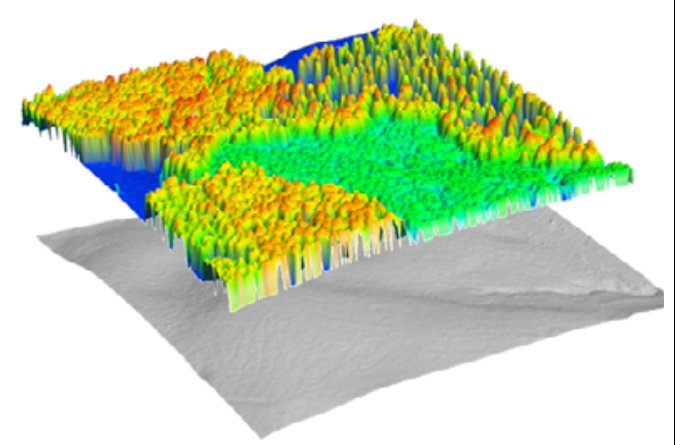

Figure 2. Images derived from lidar point-cloud data. Left, perspective view showing tree canopy height (color) overlying bare earth (gray). Right, profile view showing forest vegetation structure. Colors in both images represent elevation above the ground surface; the lowest level of vegetation is shown in dark blue. Warmer colors indicate higher elevation. Images courtesy of Robert McGaughey, U.S. Forest Service (left) and Van R. Kane, University of Washington (right).

\section{Learn More About 3DEP}

See the websites in the 3D Elevation Program sidebar and below. Please send questions to:

Director, National Geospatial Program

U.S. Geological Survey, MS 511

12201 Sunrise Valley Drive

Reston, VA 20192

- By Carol L. Ostergren, Drew Decker, and William J. Carswell, Jr.

Email: 3DEP@usgs.gov

\section{References Cited}

Dewberry, 2012, Final report of the National Enhanced Elevation Assessment (revised March 29, 2012): Fairfax, Va., Dewberry, 84 p. plus appendixes, accessed July 31, 2018, at http:/www.dewberry.com/ services/geospatial/national-enhancedelevation-assessment.

Roth, Nathaniel, 2018, California lidar-A critical investment: California Department of Conservation story map, accessed October 4, 2018, at http://cadoc.maps.arcgis. com/apps/Cascade/index.html?appid $=4 \mathrm{a} 63$ a54438f74d5db21114bec266baf4.

Sugarbaker, L.J., Constance, E.W., Heidemann, H.K., Jason, A.L., Lukas, Vicki, Saghy, D.L., and Stoker, J.M., 2014, The 3D Elevation Program initiative-A call for action: U.S. Geological Survey Circular 1399, 35 p., accessed July 31, 2018, at http://dx.doi.org/10.3133/cir1399.

The Planning Report, 2017, Gov. Brown prioritizes California's water and transportation infrastructure spending: The planning report-Insider's guide to planning and infrastructure, February 28, 2017, accessed July 31, 2018, at https://www.planningreport.com.

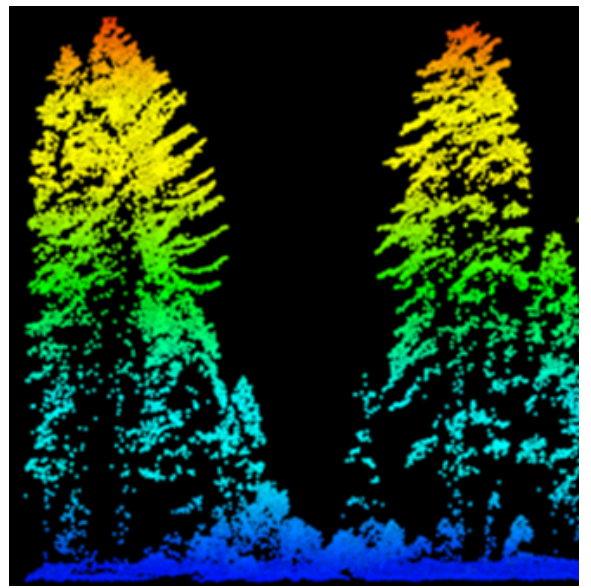

\section{USGS National Map Liaisons:}

Drew Decker; Email: ddecker@usgs.gov

https://usgs.gov/3DEP

\section{D Elevation Program (3DEP)}

The 3D Elevation Program is managed by the U.S. Geological Survey (USGS) on behalf of Federal, State, local, and other partners and users of elevation data. The goal of 3DEP is to complete the acquisition of light detection and ranging (lidar) data (interferometric synthetic aperture radar (IfSAR) data in Alaska) in 8 years to provide the first-ever national baseline of consistent, high-resolution elevation data.

\section{Benefits}

- Economies of scale by acquiring data for larger areas.

- Predictable and flexible Federal investments that reduce costs and allow better planning.

- Consistent national coverage that provides data for applications that span project, jurisdictional, and watershed boundaries.

- Simplified data acquisition that provides contracts, project management, quality assurance, and published data specifications.

- National benefits of $\$ 690$ million per year conservatively, with the potential to generate $\$ 13$ billion per year in additional benefits through applications that span the economy (Dewberry, 2012).

\section{High-Quality Data and Products}

3DEP lidar provides coverage with a minimum of two points per square meter and a vertical error not to exceed 10 centimeters, measured as root mean square error in the elevation $(z)$ dimension $\left(\mathrm{RMSE}_{z}\right.$ ) (see table 1). Lidar data products include all data points collected (point cloud) and a bare-earth digital elevation model with a 1-meter resolution. The USGS integrates the elevation data into The National Map. Data are available free of charge and without use restrictions. To download 3DEP products visit https://viewer.nationalmap.gov/basic/.

\section{Ways to Participate}

3DEP participation is open to Federal, State, Tribal, U.S. territorial, and local government partners, as well as private sector partners, and offers the option to acquire higher quality data. Partners may contribute funds toward projects managed by the USGS, or they may receive cooperative funds to manage their own projects. An annual Broad Agency Announcement is the mechanism used to establish partner agreements. Organizations and the private sector may contribute existing data that meet $3 D E P$ requirements. For more information see the 3DEP website at https://usgs.gov/3DEP/collaborate.
ISSN 2327-6916 (print)

ISSN 2327-6932 (online)

https://doi.org/10.3133/fs20193029 